\title{
Surgical treatment of bone tumors using segmental bone allografts
}

\author{
0. Ye. Vyrva $\mathbb{1}^{1, A, E, F}$, Ya. O. Holovina ${ }^{\circledR 1, A, C, D}$, R. V. Malyk ${ }^{2, B, C}$, Z. M. Danishchuk ${ }^{1, B, E}$, \\ N. O. Ashukina ${ }^{1} 1, E$, P. M. Vorontsov $(1,1, E$
}

\author{
${ }^{1}$ Sytenko Institute of Spine and Joint Pathology NAMS of Ukraine, Kharkiv, ${ }^{2}$ Kharkiv Medical Academy of Postgraduate Education, Ukraine
}

A - research concept and design; B - collection and/or assembly of data; C - data analysis and interpretation; D - writing the article; $\mathrm{E}$ - critical revision of the article; $\mathrm{F}$ - final approval of the article

The aim of the study is to improve the method of surgical treatment for patients with tumors of long bones with the use of segmental bone allograft.

Material and method. The authors have improved the method of surgical treatment of patients with tumor bone lesions using segmental allografts. Step-cut osteotomy was performed to achieve the best contact between the allograft and the recipient bone, fixation was performed with intramedullar interlocking nail without the use of bone cement, and primary bone autoplasty was done to achieve better reparation. The method was clinically tested and the results of its application were studied (radiologically, morphologically). A morphological study of the contact zone between the allograft and the recipient's bone was conducted.

Results. The effectiveness of the developed method was proved. As a follow-up result among patients who underwent surgical treatment according to the developed method, the following complications were noted: ischemic necrosis of soft tissues (due to intraoperative ligation of an artery which was surrounded by a tumor) -1 case; tumor recurrence resulting in a limb amputation -1 patient. During the macroscopic study of a removed fragment (after amputation), the fusion between allograft and recipient bone was observed. As a result of histological and X-ray examination, bone regeneration was seen in the area of contact between the allograft and the recipient bone. The histological examination also was used to clearly visualize the removed fragment of the affected tibia, in particular the contact zone between the allograft and the recipient bone, and the bone implant material, on the outer surface and internal parts of which, the formation of new bone tissue in the form of layering of the bone trabeculae was seen. Thus, the bone tissue was formed on the surface of allogeneic bone material and sprouted into its internal parts, forming a stiff bone - implant contact.

Conclusions. Using the technique of bioreconstruction of the long bone defects allows the bone tissue of the affected limb to be preserved as much as possible, to restore the surrounding soft tissues and avoid infectious and allergic reactions in comparison with modular endoprosthetics. Fixation of the allograft and the recipient bone using step-cut osteotomy with the additional insertion of an interlocking intramedullar nail allows getting a stable "construction» and maximizing the contact zone of the bone tissue (the allograft and the recipient bone).

\section{Хірургічне лікування кісткових пухлин із застосуванням сегментарних кісткових алотрансплантатів}

\section{О. Є. Вирва, Я. О. Головіна, Р. В. Малик, 3. М. Ааніщук, Н. О. Ашукіна, П. М. Воронцов}

Мета роботи - удосконалити метод хірургічного лікування хворих із кістковими пухлинами, застосовуючи сегментарні кісткові алоімплантати.

Матеріали та методи. Удосконалили метод хірургічного лікування хворих із кістковими пухлинами, застосовуючи сегментарні кісткові алотрансплантати. Виконали сходинкоподібну остеотомію для досягнення найбільшого контакту між кістковим алоімплантатом і кісткою реципієнта, фіксацію інтрамедулярним блоківним стрижнем без використання кісткового цементу, а також для досягнення кращої репарації виконували первинну кісткову аутопластику. Здійснили клінічну апробацію методу та вивчили результати застосування (рентгенологічно, морфологічно). Виконали морфологічне дослідження зони контакту алотрансплантата та кістки реципієнта.

Результати. Довели есрективність методу, що розробили. У результаті спостереження за хворими, яким виконали хірургічне лікування за розробленою методикою, визначили такі ускладнення: ішемічний некроз м'яких тканин (унаслідок інтраопераційного перев'язування артерії, що була інтимно оточена пухлиною) - 1 випадок; рецидив пухлини, що призвело до ампутації кінцівки, -1 хворий. Під час дослідження видаленого препарату (після ампутації) макроскопічно виявили зрощення алоімплантата та кістки-реципієнта. За даними гістологічного та рентгенологічного досліджень показана регенерація кістки в ділянці контакту алотрансплантата й кістки-реципієнта. У результаті гістологічного дослідження видаленого препарату ураженої гомілки, зокрема зони контакту алоімплантата й кістки-реципієнта, чітко візуалізували матеріал кісткового імплантата, на зовнішній поверхні та у внутрішніх відділах якого виявили утворення молодої кісткової тканини як нашарування кісткових трабекул. Отже, кісткова тканина формувалася на поверхні кісткового алогенного матеріалу, проростала в його внутрішні відділи, утворюючи міцний контакт «кістка - імплантат».

Висновки. Використання методики біореконструкції десректів довгих кісток дає змогу максимально зберегти кісткову тканину ураженої кінцівки, відновити навколишні тканини, уникнути інфекційних та алергічних реакцій порівняно з модульним ендопротезуванням. Фіксація алоімплантата й кістки-реципієнта, застосовуючи step-сut остеотомію з додатковим уведенням інтрамедулярного блоківного стрижня, дає змогу отримати стабільну «конструкцію» та максимально збільшити площину контакту кісткової тканини (ало- та кістки-реципієнта). Ці чинники зумовлюють хорошу кісткову регенерацію.
Key words: malignant bone tumors, osteosarcoma, bone allograft, surgical treatment.

\section{Zaporozhye} medical journa 2021; 23 (1), 159-164

*E-mail: dr.yanina.golovina@ gmail.com

Ключові слова: злоякісні кісткові пухиини, остеосаркома, кісткова алопластика, хірургічне мікування.

Запорізький медичний журнал. 2021. T. 23, № 1(124) C. $159-164$ 
Ключевые слова: злокачественные костные опухоли, остеосаркома, костная аммопластика, хирургическое мечение.

Запорожский медицинский журнал 2021. T. 23, № 1(124) C. 159-164

\section{Хирургическое лечение костных опухолей с использованием сегментарных костных аммотрансплантатов}

\section{О. Е. Вырва, Я. А. Головина, Р. В. Малык, З. Н. Аанищук, Н. А. Ашукина, П. М. Воронцов}

Цель работы - усовершенствовать метод хирургического лечения пациентов с костными опухолями с использованием сегментарных костных аллотрансплантатов.

Материалы и методы. Усовершенствовали метод хирургического лечения пациентов с костными опухолями с использованием сегментарных костных аллотрансплантатов. Выполнили ступенчатую остеотомию для достижения большего контакта между костным аллоимплантатом и костью реципиента, фиксацию интрамедуллярным блокирующим стержнем без использования костного цемента, а также для достижения лучшей репарации выполнили первичную костную аутопластику. Проведена клиническая апробация метода и изучены результаты ее применения (рентгенологически, морфологически). Выполнено морфологическое исследование зоны контакта аллотрансплантата с костью реципиента.

Результаты. Доказана эфффективность разработанного метода. В результате наблюдения за пациентами, которым проведено хирургическое лечение по разработанной методике, отмечены такие осложнения: ишемический некроз мягких тканей (вследствие интраоперационной перевязки артерии, которая была интимно спаяна с опухолью) - 1 случай; рецидив опухоли, который привел к ампутации конечности, - 1 пациент. При исследовании удаленного препарата (после ампутации) макроскопически отмечено сращение аллоимплантата и кости-реципиента. По данным гистологического и рентгенологического исследований показана регенерация кости в области контакта аллотрансплантата с костью-реципиентом. В результате гистологического исследования удаленного препарата пораженной голени, в частности зоны контакта аллоимплантата и кости-реципиента, четко визуализировали материал костного имплантата, по наружной поверхности и во внутренних отделах которого отмечено образование молодой костной ткани в виде наслоения костных трабекул. Таким образом, костная ткань формировалась на поверхности костного аллогенного материала и прорастала в его внутренние отделы, образовывая крепкий контакт «кость - имплантат».

Выводы. Использование методики биореконструкции дефектов длинных костей позволяет максимально сохранить костную ткань пораженной конечности, восстановить окружающие мягкие ткани, избежать инфекционных и аллергических реакций по сравнению с модульным эндопротезированием. Фиксация аллоимплантата и кости реципиента с использованием step-cut остеотомии с дополнительным введением интрамедуллярного блокирующего стержня позволяет получить стабильную «конструкцию» и максимально увеличить площадь контакта костной ткани (алло- и кости-реципиента). Эти условия позволят получить хорошую костную регенерацию.

Surgery for long bone tumors is the main method of treatment for patients with this pathology. An important and relevant issue is the method of post-resection segmental defects of long bones and joints replacement. Today, there are many techniques in the arsenal of orthopedists for the reconstruction of major bone and joint defects [1-6].

Among the main ones, the followings are worth to be mentioned: bone grafting, the method of distraction osteogenesis, replacement of defects by biomaterials (demineralized bone matrix and ceramic implants), and endoprosthetics. The methods of bone grafting include autografting (with the use of cancellous, cortical and autoclaved autografts), allografting and xenografting. However, nowadays, combined methods for replacing large segmental bone and joint defects are becoming increasingly popular. To reduce the bone defect and recover soft tissue defects, the allograft-prosthetic composite (APC) technique was developed. This technique has been used since the late 80 's of the past century. Currently, it is proved that the use of this type of surgical treatment allows for biological restoration by providing an allograft attachment to the surrounding soft tissues, which leads to better functional recovery of the muscles and affected joints and the entire limb $[7,8]$.

Optimal implants to replace bone and joint defects have been under development for many decades. In order to select the «ideal» implant, which must meet the requirements of biocompatibility, mechanical stability and be safe, it is necessary to conduct a number of studies and tests $[9,10]$. Therefore, the method of allograft-prosthetic composite is of interest to detailed studies.

\section{Aim}

The objective of the study is to improve the method of surgical treatment for patients with tumors of long bones with the use of segmental bone allograft.

\section{Material and methods}

In order to target better results of surgical treatment for patients with bone tumors, we have improved the method of post-resection segmental defects of long bones and joints replacement. Segmental bone allografts (articulating or without preserved metaepiphyseal (diaphyseal) zone) were used as a replacement material. Bone allografts were made at the Transplantology Department of Sytenko Institute of Spine and Joint Pathology NAMS of Ukraine. A donor bone was mechanically cleaned from soft tissue, cartilage, and periosteum. An organic component with antigenic properties was removed by chemical procedures. A harvested sample was packed and exposed to radiation sterilization. Processing of the bone was performed according to the developed in Sytenko Institute of Spine and Joint Pathology NAMS of Ukraine technical specifications and patented original method of manufacturing implants using bone tissue (certificate of compliance No. UA.TR 101-21-2016).

The first stage of surgery was ablastic radical en block removal of the bone tumor (segmental resection). Express biopsy - a cytological examination of the bone marrow from the medullary canal to identify atypical cells - was performed and, if necessary, the area of affected bone resection was extended. Step-cut osteotomy was performed 
in the area of cut bone. One end of the segmental articulating allograft was processed so that its protruding parts and parts of the recipient bone were properly positioned by "the Russian lock" type (Fig. 1).

The second stage was the long bone post-resection defect replacement. An interlocking nail was inserted into the intramedullary canal of the segmental allograft, and it was blocked with screws. The free part of the nail was inserted into the medullary canal of the recipient bone in such a way that the edges of the allograft and the recipient bone were completely matched. Following that, the nail was blocked in the recipient bone. The interlocking nail was implanted without using of bone cement. In the contact area between the allograft and the recipient bone, free bone autotransplants (from the local tissues) were additionally placed and fixed to each other using sutures (Fig. 2). After performing the bone defect replacement, a thorough restoration of the surrounding muscles was performed.

In the case of using a segmental allograft for replacing large diaphyseal defects in long bones, step-cut osteotomy was performed at both ends of the implant. In these cases, the interlocking nail was blocked by screws in the recipient bone proximally and distally. Additionally, bone autografting from the fibula was performed.

This technique was used in 5 patients $(3$ men and 2 women) with malignant tumors of long bones. The distribution by nosology was as follows: osteogenic sarcoma -2 patients, adamantinoma - 1 patient, undifferentiated pleomorphic sarcoma -2 patients. The mean age of the patients was 35.6 years (from 18 to 50 years). 3 patients had the pathological tumor focus located in the distal part of the tibia. In these cases, a segmental articulating allograft was used to replace a post-resection bone defect. A segmental diaphyseal allograft was used to replace post-resection bone defects in 2 patients who had the tumor process located in the diaphyseal zone of the femur.

According to the treatment protocols, 4 patients with malignant bone tumors underwent polychemotherapy.

All the patients underwent $X$-ray and computed tomography $(\mathrm{CT})$ examinations during the postoperative period to control the reparative processes, as well as to monitor the oncologic process.

In one case, a patient with adamantinoma of the distal tibia underwent lower limb amputation at the level of the lower third of the femur due to a recurrent tumor. The removed fragment of the tibia was examined in a pathomorphological laboratory. The contact area between allograft and recipient bone was studied directly.

Histological examination. The tibia with allograft was removed from the amputated limb. The areas of the recipient tissue fusion with the allograft were taken for the study. The material was fixed in $10 \%$ neutral formalin, decalcified in formic acid solution, dehydrated through an ethanol series and embedded in paraffin. The histological sections were stained with hematoxylin and eosin, and Van Gieson picrofuxin, then were analyzed using a light microscope Olympus BX63. A digital camera DP73 (Olympus) and the software "Cell Sens Dimension 1.8.1" (Olympus, 2013) were used for photographing.

Ethical approval. The authors declare that all the procedures and experiments of this study met the ethical standards in the Helsinki Declaration of 1975, revised in

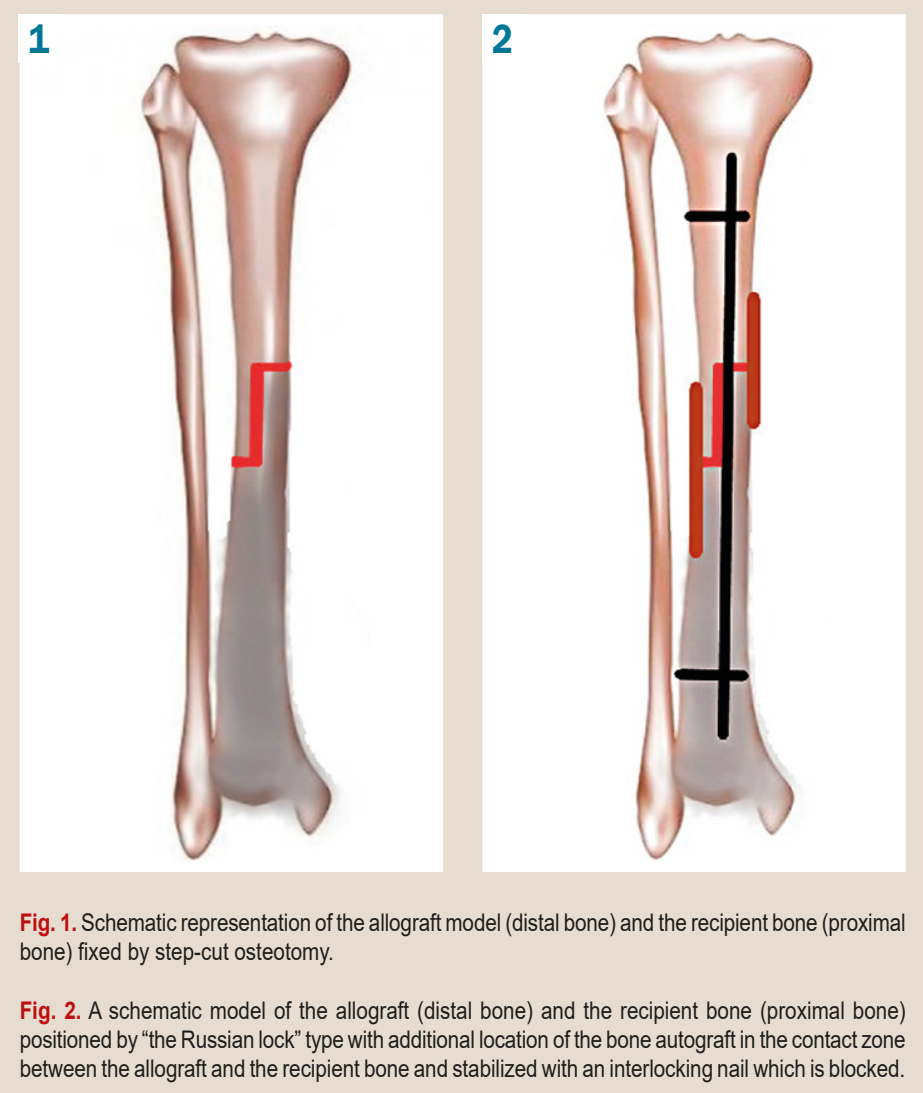

2008(5), as well as the national law. An informed consent was obtained from all the patients included in the study.

\section{Results}

As follow-up results among patients who underwent surgical treatment according to the developed method, the following complications were noted: ischemic necrosis of soft tissues (due to intraoperative ligation of an artery that was surrounded by a tumor) -1 case; tumor recurrence resulting in limb amputation -1 patient. A patient with soft tissue necrosis in the area of surgery had skin and muscle plastic surgery, and thus it helped to save the limb. In all the cases, the fusion between the allograft and the recipient bone was observed in a 6-month follow-up period.

Morphological findings. During the macroscopic examination of a removed fragment, the allograft and recipient bone fusion was observed (Fig. 3).

As a result of histological examination of the removed fragment of the affected tibia, in particular the contact zone between the allograft and the recipient bone, the bone implant material was clearly visualized. On its outer surface and internal parts, the formation of new bone tissue in the form of layering of the bone trabeculae was seen. The bright eosinophilic matrix contained dense large osteocytes, osteocytic lacunae were devoid of cells. That is, the cells were at the maturation stage, being actively involved in the synthesis of matrix components, and having an osteoblast-like structure, and consequently, trabeculae of woven bone. A layer of osteoblasts with various functional activity was located on the outer surface of the bone trabeculae. In addition to bone trabeculae, blood capillaries, cells at less 


\section{Кминический случай}
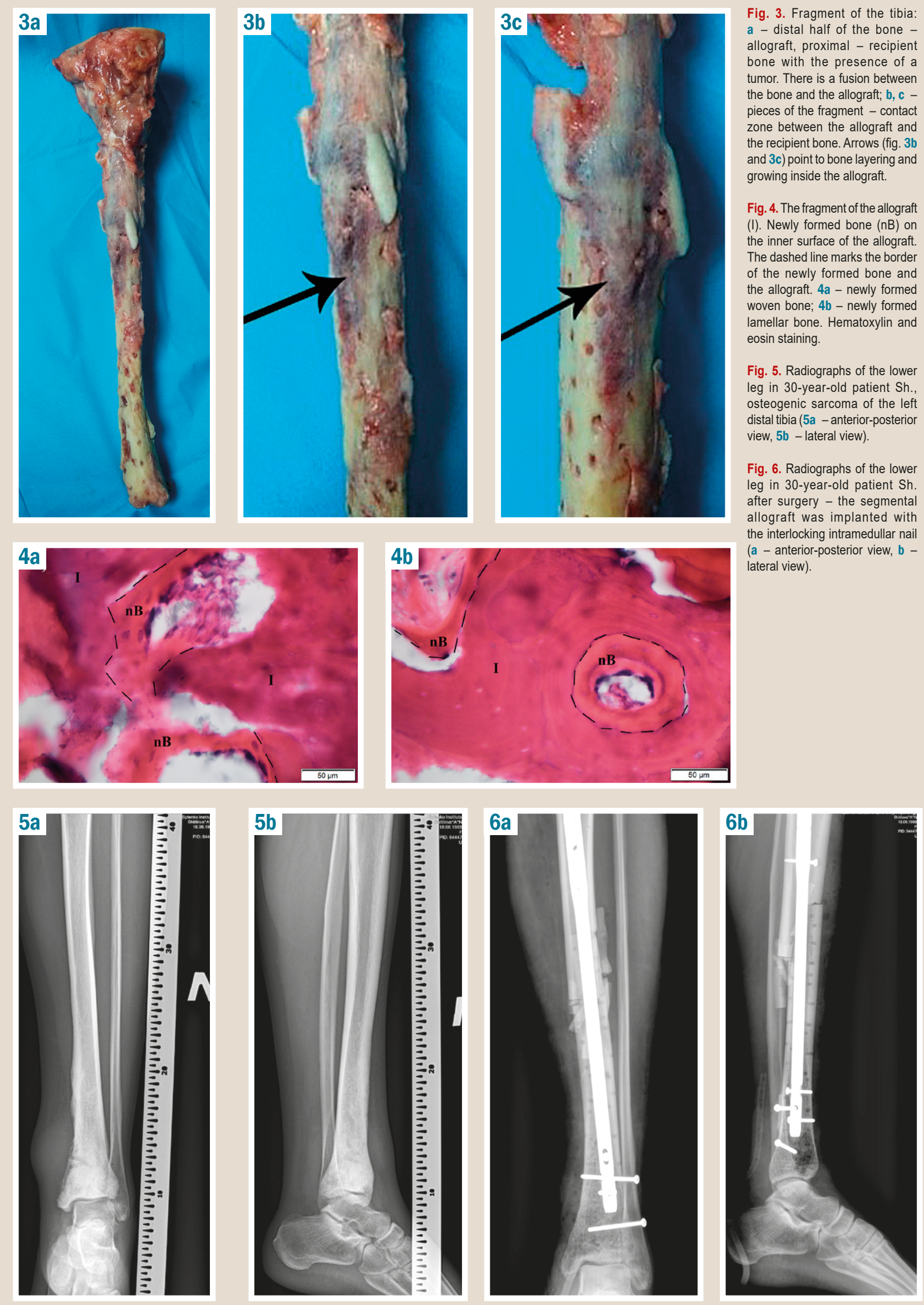

Fig. 3. Fragment of the tibia: a - distal half of the bone allograft, proximal - recipient bone with the presence of a tumor. There is a fusion between the bone and the allograft; b, c pieces of the fragment - contact zone between the allograft and the recipient bone. Arrows (fig. 3b and $3 \mathrm{c}$ ) point to bone layering and growing inside the allograft.

Fig. 4. The fragment of the allograft (I). Newly formed bone (nB) on the inner surface of the allograft. The dashed line marks the border of the newly formed bone and the allograft. $4 a-$ newly formed woven bone; $4 \mathrm{~b}$ - newly formed lamellar bone. Hematoxylin and eosin staining.

Fig. 5. Radiographs of the lower leg in 30-year-old patient Sh., osteogenic sarcoma of the left distal tibia (5a -anterior-posterior view, 5b - lateral view).

Fig. 6. Radiographs of the lower leg in 30-year-old patient Sh. after surgery - the segmental allograft was implanted with the interlocking intramedullar nail (a - anterior-posterior view, b lateral view). 
mature differentiation stage, and fibroblasts were observed on the internal allograft surface (Fig. 4).

Thus, bone tissue was formed on the surface of allogeneic bone material and sprouted into its internal parts, forming a stiff bone - implant contact.

\section{Case report}

A 30-year-old patient Sh. was hospitalized to Sytenko Institute of Spine and Joint Pathology clinic with complaints of pain and the presence of enlarging mass in the distal third of the left lower leg. She did not receive any treatment previously. The patient underwent a comprehensive examination, X-ray and CT examination (contrast-enhanced), and a biopsy of the tibial mass. Lytic destruction of the distal tibia with disrupted integrity of the cortical layer was visible on radiographs (Fig. 5). CT scans showed lytic destruction of the lower third of the tibia with a large soft tissue component without major vessel invasion and with the presence of tumor-feeding arteries. CT-cancer screening of organs and systems of the body did not show metastatic lesions.

During a histological analysis of the biopsy material, osteogenic sarcoma was diagnosed. Thus, the comprehensive examination of the patient resulted in a diagnosis: osteogenic sarcoma of the left distal tibia T2NOM0 stage II, clinical group II. According to the protocols of this nosology treatment, polychemotherapy and surgery were performed. Surgery: en block removal of the tumor, replacement of the post-resection defect of the distal tibia with segmental articulating allograft, the allograft and the recipient bone fixation with the interlocking nail. Autoplasty of the contact zone between the allograft and the recipient bone was additionally performed (Fig. 6). After the operation, the lower limb was immobilized for 3 months with a circular plaster cast with a walking stirrup leaning on the lower limb. At that time, the patient received courses of polychemotherapy. Final radiographs (6 months after the surgery) showed signs of reparation in the contact area between the allograft and the recipient bone (Fig. 7). In 6 months, the patient walks with a full load on the operated lower limb without additional support. In total, the patient was followed-up for 1.5 years. There were no signs of tumor recurrence or other complications.

\section{Discussion}

In previous studies, segmental bone allografts were fixed in the recipient bone with the help of the endoprosthesis stem or bone plates and intramedullary nail [11-13]. In most cases, a transverse osteotomy was performed and bone cement was used in the case of fixation with the endoprosthesis stem [14]. Articulating allografts were more often used in the case of the proximal humerus destruction [15]. We have studied the complications of existing methods of allograft-prosthetic composite and taken into account to improve this technique. We performed step-cut osteotomies to achieve the best contact between the allograft and the recipient bone, fixation with intramedullar interlocking nails without the use of bone cement, and primary bone autoplasty was performed to achieve better reparation.
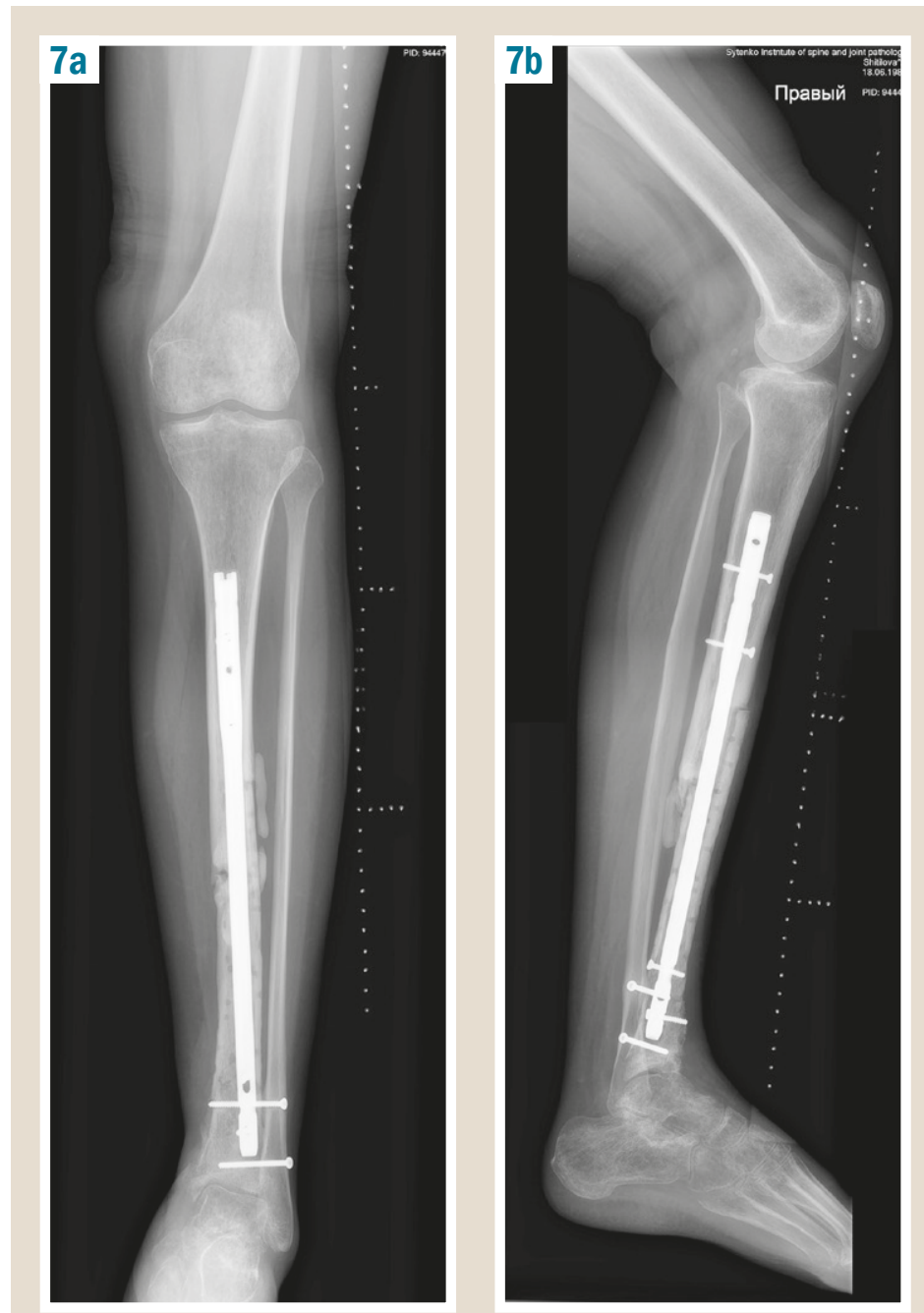

Fig. 7. Radiographs of the lower leg in 30-year-old patient Sh., 6 months after the surgery - there are signs of reparation in the contact zone between the allograft and the recipient bone (a -anteriorposterior view, b - lateral view).

\section{Conclusions}

1. The use of the bioreconstructive technique for long bone defects allows the bone tissue of the affected limb to be preserved as much as possible, to restore the surrounding soft tissues and avoid infectious and allergic reactions in comparison with modular endoprosthetics.

2. Fixation of the allograft and the recipient bone using step-cut osteotomy with the additional insertion of an interlocking intramedullar nail allows getting a stable "construction" and maximizing the contact zone of the bone tissue (the allograft and the recipient bone). These conditions allow getting good bone regeneration.

3. Cement-free insertion of a metal nail also helps to avoid such complications as cement leakage into the contact zone between the allograft and the recipient bone, and the development of metal implant instability.

\section{Funding}

The article was written within the framework of the research work "To develop methods of bioreconstruction of long bones and joints defects at surgical treatment of patients with bone tumors". No. $0118 \cup 003215$ 
Conflicts of interest: authors have no conflict of interest to declare. Конфлікт інтересів: віАсутній.

Надійшла Ао реАакції / Received: 18.09.2020

Після Аоопрацювання / Revised: 19.10.2020

Прийнято Ао Аруку / Accepted: 23.10.2020

\section{Information about authors:}

Vyrva O. Ye., MD, PhD, DSc, Professor, Head Physician, Head of the Bone Tumor Department, Sytenko Institute of Spine and Joint Pathology National Academy of Medical Sciences of Ukraine, Kharkiv.

ORCID ID: 0000-0003-0597-4472

Holovina Ya. O., MD, PhD, Senior Researcher of the Bone Tumor Department, Sytenko Institute of Spine and Joint Pathology National Academy of Medical Sciences of Ukraine, Kharkiv. ORCID ID: 0000-0002-1605-9109

Malyk R. V., MD, PhD, Assistant of the Traumatology and Orthopaedics Department, Kharkiv Medical Academy of

Postgraduate Education, Ukraine.

ORCID ID: 0000-0001-9070-4834

Danishchuk Z. M., Researcher of the Laboratory of Morphology of Connective Tissue, Sytenko Institute of Spine and Joint Pathology National Academy of Medical Sciences of Ukraine, Kharkiv. ORCID ID: 0000-0003-2968-3821

Ashukina N. O., PhD, Head of the Laboratory of Morphology of Connective Tissue, Sytenko Institute of Spine and Joint Pathology National Academy of Medical Sciences of Ukraine, Kharkiv. ORCID ID: 0000-0002-0478-7440

Vorontsov P. M., MD, PhD, Head of the Department of Transplantology and Experimental Modeling with an Experimental Biologic Clinic, Sytenko Institute of Spine and Joint Pathology National Academy of Medical Sciences of Ukraine, Kharkiv.

\section{ORCID ID: 0000-0002-5758-7223}

\section{Відомості про авторів:}

Вирва О. Є., А-р меА. наук, професор, зав. відыілу кісткової онкології, головний лікар, АУ «Інститут патології хребта та суглобів імені професора М. І. Ситенка НАМН України", м. Харків. Головіна Я. О., канА. меА. наук, старший науковий співробітник відаілу кісткової онкології, АУ «Інститут патології хребта та суглобів імені професора М. І. Ситенка НАМН України", м. Харків. Малик Р. В., канА. меА. наук, асистент каф. травматології та ортопеАії, Харківська медична академія післядипломної освіти, Україна.

Ааніщук 3. М., наук. співробітник лабораторії морфології сполучної тканини, АУ «нститут патології хребта та суглобів імені професора

М. І. Ситенка НАМН України", м. Харків.

Ашукіна Н. О., канА. біол. наук, зав. лабораторії морфології сполучної тканини, АУ «нститут патології хребта та суглобів імені професора М. І. Ситенка НАМН України", м. Харків. Воронцов П. М., канА. меА. наук, зав. відіілу експериментального моделювання та трансплантології з експериментально-біологічною кінікою, АУ «нститут патології хребта та суглобів імені професора М. І. Ситенка НАМН України", м. Харків.

\section{Сведения об авторах:}

Вырва О. Е., А-р меА. наук, профессор, главный врач, зав. отАелом костной онкологии, ГУ «Институт патологии позвоночника и суставов имени профессора М. И. Ситенко НАМН Украины", г. Харьков.

Головина Я. А., канА. меА. наук, старший научный сотрудник отАела костной онкологии, ГУ “Институт патологии позвоночника и суставов имени профессора М. И. Ситенко НАМН Украины", г. Харьков.

Малык Р. В., канд. меА. наук, ассистент каф. травматологии и ортопедии, Харьковская медицинская академия последипломного образования, Украина.

Аанищук 3. Н., научный сотруаник лаборатории морфологии соеАинительной ткани, ГУ «Институт патологии позвоночника и суставов имени профессора М. И. Ситенко НАМН Украины", г. Харьков.

Ашукина Н. А., канд. биол. наук, зав. лабораторией морфологии соеАинительной ткани, ГУ «Институт патологии позвоночника и суставов имени профессора М. И. Ситенко НАМН Украины", г. Харьков.
Воронцов П. М., канА. меА. наук, зав. отАелом экспериментального моделирования и трансплантологии с экспериментально-биологической кииникой, ГУ «Институт патологии позвоночника и суставов имени профессора М. И. Ситенко НАМН Украины", г. Харьков.

\section{References}

[1] Mayle, R. E., Jr, \& Paprosky, W. G. (2012). Massive bone loss: allograft-prosthetic composites and beyond. The Journal of Bone and Joint Surgery. British volume, 94-B(11 Suppl. A), 61-64. https://doi. org/10.1302/0301-620X.94B11.30791

[2] Gharedaghi, M., Peivandi, M. T., Mazloomi, M., Shoorin, H. R. Hasani, M., Seyf, P., \& Khazaee, F. (2016). Evaluation of Clinica Results and Complications of Structural Allograft Reconstruction after Bone Tumor Surgery. The Archives of Bone and Joint Surgery, 4(3), 236-242.

[3] Calabró, T., Van Rooyen, R., Piraino, I., Pala, E., Trovarelli, G. Panagopoulos, G. N., Megaloikonomos, P. D., Angelini, A., Mavrogenis, A. F., \& Ruggieri, P. (2016). Reconstruction of the proximal femur with a modular resection prosthesis. European Journal of Orthopaedic Surgery \& Traumatology, 26(4), 415-421. https://doi.org/10.1007/ s00590-016-1764-0

[4] Vyrva, O. E., Golovina, Ya. A., \& Malyk, R. V. (2015). Allokompozitnoe endoprotezirovanie pri khirurgicheskom lechenii patsientov so zlokachestvennymi opukholyami dlinnykh kostei (obzor literatury) [Allograft-prosthesis composite for surgical treatment in patients with malignant tumors of the long bones (review)]. Ortopediya, travmatologiya i protezirovanie, (2), 120-125. https://doi.org/10.15674/0030598720152120-125 [in Russian]

[5] Min, L., Tang, F., Duan, H., Zhou, Y., Zhang, W. L., Shi, R., \& Tu, C. Q. (2015). Cemented allograft-prosthesis composite reconstruction for the proximal femur tumor. OncoTargets and Therapy, 8, 2261-2269. https://doi.org/10.2147/OTT.S85788

[6] Subhadrabandhu, S., Takeuchi, A Yamamoto, N Shirai, T, Nishida, H., Hayashi, K., Miwa, S., \& Tsuchiya, H. (2015). Frozen Autograft-Prosthesis Composite Reconstruction in Malignant Bone Tumors. Orthopedics, 38(10), e911-e918. https://doi.org/10.3928/0147744720151002-59

[7] Benedetti, M. G., Bonatti, E., Malfitano, C., \& Donati, D. (2013). Comparison of allograft-prosthetic composite reconstruction and modula prosthetic replacement in proximal femur bone tumors: functional assessment by gait analysis in 20 patients. Acta Orthopaedica, 84(2) 218-223. https://doi.org/10.3109/17453674.2013.773119

[8] McGoveran, B. M., Davis, A. M., Gross, A. E., \& Bell, R. S. (1999) Evaluation of the allograft-prosthesis composite technique for proximal femoral reconstruction after resection of a primary bone tumour. Canadian Journal of Surgery, 42(1), 37-45.

[9] Summers, S. H., Zachwieja, E. C., Butler, A. J., Mohile, N. V., \& Pretell-Mazzini, J. (2019). Proximal Tibial Reconstruction After Tumor Resection: A Systematic Review of the Literature. JBJS Reviews, 7(7) e1. https://doi.org/10.2106/JBJS.RVW.18.00146

[10] Donati, D., Colangeli, M., Colangeli, S., Di Bella, C., \& Mercuri, M. (2008). Allograft-Prosthetic Composite in the Proximal Tibia After Bone Tumor Resection. Clinical Orthopaedics and Related Research, 466(2), 459-465. https://doi.org/10.1007/s11999-007-0055-9

[11] Hornicek, F. J., Gebhardt, M. C., Tomford, W. W., Sorger, J. I., Zavatta, M., Menzner, J. P., \& Mankin, H. J. (2001). Factors Affecting Nonunion of the Allograft-Host Junction. Clinical Orthopaedics and Related Research, 382, 87-98. https://doi.org/10.1097/00003086200101000-00014

[12] Miller, B. J., \& Virkus, W. W. (2010). Intercalary Allograft Reconstructions Using a Compressible Intramedullary Nail: A Preliminary Report. Clinica Orthopaedics and Related Research, 468(9), 2507-2513. https://doi. org/10.1007/s11999-010-1260-5

[13] Puerta-GarciaSandoval, P., Lizaur-Utrilla, A., Trigueros-Rentero, M. A. \& Lopez-Prats, F. A. (2019). Mid- to long-term results of allograft-prosthesis composite reconstruction after removal of a distal femora malignant tumor are comparable to those of the proximal tibia. Knee Surgery, Sports Traumatology, Arthroscopy, 27(7), 2218-2225. https:// doi.org/10.1007/s00167-018-5110-4

[14] Hu, C. C., Chen, S. Y., Chen, C. C., Chang, Y. H., Ueng, S. W., \& Shih, H. N. (2017). Superior Survivorship of Cementless vs Cemented Diaphyseal Fixed Modular Rotating-Hinged Knee Megaprosthesis at 7 Years' Follow-Up. The Journal of Arthroplasty, 32(6), 1940-1945. https:// doi.org/10.1016/j.arth.2016.12.026

[15] Teunis, T., Nota, S. P., Hornicek, F. J., Schwab, J. H. \& Lozano-Calderón, S. A. (2014). Outcome After Reconstruction of the Proximal Humerus for Tumor Resection: A Systematic Review. Clinical Orthopaedics and Related Research, 472(7), 2245-2253. https://doi. org/10.1007/s11999-014-3474-4 